\section{JURNAL ABDIMAS

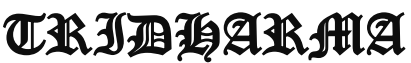

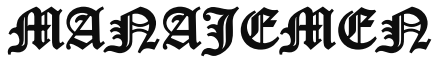

P-ISSN 2615-6849, E-ISSN 2716-070X

Jurnal ABDIMAS Vol. 1,No.2, Mei 2020,Hal(117-124)

@Prodi Manajemen Fakultas Ekonomi Universitas Pamulang

Email: abdimasjurnal.unpam@gmail.com Telp: (021) 741-2566

\title{
STRATEGI PEMASARAN USAHA KREATIF DAUR ULANG LIMBAH ANORGANIK PADA BANK SAMPAH ASRI BERSERI DIPERUMAHAN GRIYA PAMULANG ASRI RT. 06 / RW.009 BENDA BARU PAMULANG TANGERANG SELATAN - BANTEN
}

\author{
Yenni Cahyani, Suciati Muanifah, Yulianto, Syamsul Mu'arif \\ Dosen Ekonomi Fakultas Ekonomi Universitas Pamulang \\ Email: yennicahyani6@gmail.com
}

\begin{abstract}
ABSTRAK
Program Pemanfaatan pengolahan sampah berupa pemanfaatan sampah rumah tangga menjadi industri kerajinan tangan yang kreatif semakin giat dikembangkan oleh berbagai daerah di Indonesia, program ini juga berkembangan di kecamatan Benda Baru, Tangerang Selatan - Banten di kecamatan ini pada perumahan Griya Asri Pamulang terdapat kelompok kecil Bank Sampah yang bernama BANK SAMPAH ASRI BERSERI adalah Ibu- ibu rumah tangga.

Persoalan utama yang dihadapi oleh kelompok ibu-ibu ini adalah pada pemasaran hasil produk, salah satu upaya yang ingin dikembangkan adalah memasarkan produk kerajinan ini baik melalui off line dengan membuka gerai toko atau pun melalui jejaring social seperti facebook, whattshap, instagram sebagai upaya promosi, yang sementara ini promosi yang dilakukan masih seputaran mengenal produk produk tersebut pada wilayah sekitar dan teman - teman grup. Keputusan pengambilan tema ini diawali dari hasil survey dan interaksi dengan pengurus BANK SAMPAH maupun dengan anggota bank sampah yang melakukan aktivitas membuat kerajinan tangan dari hasil daur ulang sampah. Pelatihan strategi pemasaran ini dilakukan dengan memberikan penyuluhan bagaimana stategi yang tepat dalam memasarkan produk ini. Luaran yang dihasilkan oleh program ini adalah ketrampilan yang dimiliki oleh para pengurus dan anggota bank sampah dalam bentuk kemampuan memasarkan produk olahan daur ulang sampah sehingga terbentuk ekonomi produktif.

Khalayak sasaran sasaran yang akan menerima kegiatan penyuluhan ini adalah Pengurus dan anggota Bank Sampah Asri Berseri, yang kesemua nya adalah ibu - ibu Rumah Tangga, bahwa pertimbangan memilih kaum ibu adalah karena ibu berperan penting dalam mengatur jalannya roda rumah tangga atau keluarga dan penyumbang sampah rumah tangga terbesar dalam aktivitas rumah tangganya sehari-hari.

Realisasi Pemecahan permasalahan adalah dengan melakukan acara kunjungan ke Bank Sampah Griya Asri dan memberikan penyuluhan pengetahuan terkait dengan Strategi Pemasaran usaha kreatif daur ulang sampah anorganik dalam bentuk seminar.Diharapkan dengan adanya kegiatan ini dapat merintis dan mengembangkan usaha yang sekarang hanya dikelola secara tradisional perorangan menjadi usaha ekonomi mikro produktif, terutama dalam hal pemasaran hasilnya, maka dengan adanya program ini mitra dapat meningkatkan pemasaran hasilnya melalui kelembagaan usaha yang lebih konvensional dan aplikatif dan Pengurus dan anggota memiliki keterampilan mengelola dan mengembangkan pemasaran produk hasil daur ulang sampah baik secara offline maupun online sehingga dapat meingkatkan volume penjualan produk kerajinannya, sehingga berdampak pada peningkatan pendapatan mitra.
\end{abstract}




\section{JURNAL ABDIMAS

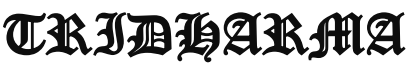

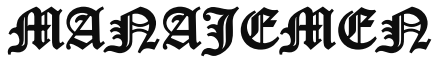

P-ISSN 2615-6849, E-ISSN 2716-070X

Jurnal ABDIMAS Vol. 1,No.2, Mei 2020,Hal(117-124)

@Prodi Manajemen Fakultas Ekonomi Universitas Pamulang

Email: abdimasjurnal.unpam@gmail.com Telp: (021) 741-2566

\title{
Kata Kunci: Strategi Pemasaran, Ekonomi Produksti, Promosi
}

\begin{abstract}
ABSTRAC
The Waste Utilization Program in the form of household waste utilization into a creative handicraft industry is increasingly actively being developed by various regions in Indonesia, this program is also developing in Benda Baru sub-district, South Tangerang Banten in this sub-district in Griya Asri Pamulang housing there is a small group of Garbage Bank named BANK SAMPAH ASRI BERSERI are housewives.

The main problem faced by this group of mothers is the marketing of product results, one of the efforts to be developed is to market these handicraft products either off line by opening store outlets or through social networks such as Facebook, whattshap, instagram as promotional efforts, while the promotion is still being done around the products in the surrounding area and group friends. The decision to take this theme begins with the results of surveys and interactions with the management of the SAMPAH BANK and with members of the garbage bank who carry out activities to make handicrafts from recycled waste. This marketing strategy training is carried out by providing counseling on the right strategy in marketing this product. The output produced by this program is the skills possessed by the management and members of the waste bank in the form of the ability to market processed waste recycling products so that a productive economy is formed.

The target audiences who will receive this extension activity are the Board and members of the Asri Garbage Bank, which are all housewives, that the consideration of choosing mothers is because mothers play an important role in managing the running of the household or family wheels and contributors to household waste the biggest ladder in daily household activities.

Realization of the solution of the problem is by conducting a visit to the Griya Asri Garbage Bank and providing knowledge counseling related to the Marketing Strategy of inorganic waste recycling creative business in the form of a seminar. Hopefully with this activity it can pioneer and develop businesses that are now only traditionally managed individually into businesses productive microeconomics, especially in terms of marketing the results, the presence of this program partners can improve the marketing of the results through more conventional and applicable business institutions and the Management and members have the skills to manage and develop the marketing of waste recycled products both offline and online so that they can increase the volume of sales of handicraft products, so that the impact on increasing partner income.
\end{abstract}

\section{Keywords: Marketing Strategy, Production Economics, Promotion}

\section{PENDAHULUAN}

Pertambahan jumlah penduduk, perubahan pola konsumsi, dan gaya hidup masyarakat telah meningkatkan jumlah timbulan sampah, jenis, dan keberagaman karakteristik sampah. Meningkatnya daya beli masyarakat terhadap berbagai jenis bahan pokok dan hasil teknologi serta meningkatnya usaha atau kegiatan penunjang pertumbuhan ekonomi suatu daerah juga memberikan kontribusi yang besar terhadap kuantitas dan kualitas sampah yang dihasilkan. Meningkatnya volume timbulan sampah memerlukan pengelolaan. Pengelolaan sampah yang tidak mempergunakan metode dan teknik pengelolaan sampah yang ramah lingkungan selain akan dapat menimbulkan dampak negatif terhadap kesehatan juga akan sangat mengganggu kelestarian fungsi lingkungan baik lingkungam pemukiman, hutan, persawahan, sungai dan lautan. Mencermati fenomena di atas maka sangat diperlukan model pengelolaan sampah yang baik dan tepat dalam upaya mewujudkan perkotaan dan perdesaan yang bersih dan hijau. 


\section{JURNAL ABDIMAS

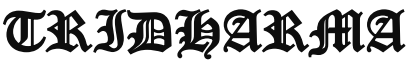

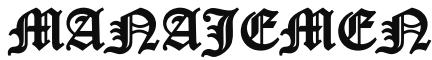

P-ISSN 2615-6849, E-ISSN 2716-070X

Jurnal ABDIMAS Vol. 1,No.2, Mei 2020,Hal(117-124)

@Prodi Manajemen Fakultas Ekonomi Universitas Pamulang

Email: abdimasjurnal.unpam@gmail.com Telp: (021) 741-2566
Ada banyak sekali alasan mengapa daur ulang limbah harus dilakukan. Dengan melakukan daur ulang terhadap berbagai macam material, akan mengurangi sampah yang harus dibuang. Maka lahan yang dibutuhkan untuk menimbun sampahsampah akan berkurang.

Dengan munculnya peluang bisnis kreatif daur ulang limbah, dapat mengurangi jumlah limbah yang menumpuk serta memberikan keuntungan yang cukup besar bagi pelaku bisnisnya. Limbah sampah yang dihasilkan masyarakat, dengan kreativitas dan inovasi dari para pelaku bisnis, limbah sampah dapat didaur ulang dan dirubah menjadi produk baru yang memiliki nilai ekonomi lebih tinggi. Banyaknya sampah dimanfaatkan oleh sebagian masyarakat yang kreatif menjadi peluang bisnis yang menguntungkan.

Untuk mengatasi pertumbuhan dan penyebaran sampah plastik yang relatif masif, maka berbagai cara dilakukan supaya sampah plastik ini dapat dimanfaatkan menjadi produk bernilai ekonomi. Langkah tersebut antara lain memanfaatkan sampah plastik sebagai bahan baku pembuatan berbagai produk kerajinan tangan. Pemanfaatan sampah plastik sudah banyak dilakukan oleh kelompok usaha kerajinan di berbagai daerah, bahwa hasil kerajinan tangan berbahan plastik. Produk kerajinan tangan yang dihasilkan diantaranya tas, wadah tisu, tempat pensil, sandal, kipas tangan, wadah hantaran, taplak meja, bunga-bunga hias dan beragam souvenir-souvenir.

Masalah Mitra dalam penelitian ini untuk mengetahui bagaimana Kualitas keterampilan dalam mengelola sampah daur ulang, untuk mengetahui bagaimana Produk yang sudah dihasilkan mampu dipasarkan, untuk mengetahui Pengelolaan manajemen usaha, untuk mengetahui Pemilihan strategi marketing yang tepat, dan ntuk mengetahui bagaimana mitra memiliki ketrampilan dalam mengembangkan dan memasarkan produk hasil usaha melalui pemasaran yang bersifat konvensional maupun online.

Manfaat dalam pengabdian ini dalam masyarakat pada umumnya dan khususnya pengurus dan anggota Bank Sampah Asri Berseri, yang beralamat di Jl. Inpres perum Griya Pamulang Asri Benda Baru Pamulang Tangsel RT 06/ RW 009 agar mereka mampu mengelolah sampah dan mampu menjadikan sampah sebagai komuniti yang menghasilkan nilai ekonomis, sedangkan manfaat bagi akademinisi menjadi sebuah sarana pengabdian dan menambah wawasan dalam meningkatkan kualitas dan kuatitas pengembangan profesi.

\section{RUMUSAN MASALAH}

Pengabdian Kepada Masyarakat ini dilaksanakan pada hari Jum'at - Minggu, Tgl. 25 - 27 Oktober 2019. Tempat pelaksanaan adalah Bank Sampah Asri Berseri, griya Pamulang Asri Benda Baru Pamulang - Tangerang Selatan Sasaran pengabdian masyarakat ini tentu saja adalah para warga di Griya Pamulang Asri RT. 06 / RW.09 Benda Baru - Pamulang Tangerang Selatan dan pada khususnya adalah pengurus dan anggota Bank Sampah Griya Asri.

Seminar yang yang diberikan berfokus pada strategi pemasaran yang jitu serta kendala- kendala yang harus dihadapai dalam memasarkan produk dalam hal ini TIM PKM memberikan gambaran tentang Analisis SWOT serta Bauran Pemasaran yang terkait dengan 4P. Setelah diberikan gambaran strategi maka Tim PKM melakukan telaah dari rumusan tersebut, mana yang menjadi kendala dalam strategi pemasaran apakah terkait promosi dan sitem pemasaran yang masih tradisonal atau ruang lingkung pangsa pasarnya yang terbatas, dari telaah tersebut Tim membuat kesimpulan serta Peta Pemasaran yang memudahkan pengurus bank sampah untuk terus mengevaluasi serta mengembangkan pemasarannya.

Metode pelaksanaan program ini melalui beberapa tahap sebagai berikut: 1) Persiapan Kegiatan, yang berisi perijinan, 


\section{JURNAL ABDIMAS

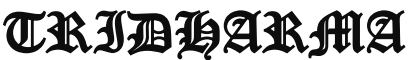

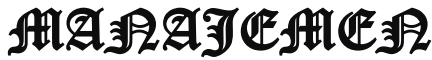

P-ISSN 2615-6849, E-ISSN 2716-070X

Jurnal ABDIMAS Vol. 1,No.2, Mei 2020,Hal(117-124)

@Prodi Manajemen Fakultas Ekonomi Universitas Pamulang

Email: abdimasjurnal.unpam@gmail.com Telp: (021) 741-2566 pengamatan kondisi masyarakat, analisis program, dan perencanaan dan pembuatan program. 2) Pelaksanaan Kegiatan, yang berisi seminar program, evaluasi program, dan pembuat laporan

\section{TUJUAN PELAKSANAAN}

Tujuan dalam kegiatan pengabdian ini untuk memberikan pengetahuan bagaimana Kualitas keterampilan dalam mengelola sampah daur ulang, untuk memberikan pengetahui bagaimana Produk yang sudah dihasilkan mampu dipasarkan, untuk memberikan pengetahuan Pengelolaan manajemen usaha, untuk memberikan pengetahua mengetahui Pemilihan strategi marketing yang tepat, dan untuk mengetahui Mitra belum memiliki ketrampilan dalam mengembangkan dan memsarkan produk hasil usaha melalui pemasaran yang bersifat konvensional maupun online.

\section{TINJAUAN PUSTAKA}

\section{Pengertian Manajemen}

Pengertian manajemen secara umum dapat disimpulkan dari beberapa definisi menurut para ahli. Hal ini karena ada banyak versi definisi manajemen. Misalnya saja manajemen menurut seorang ahli bernama Mary Parker Follet yang mendefinisikan manajemen sebagai seni merampungkan pekerjaan melalui orang lain. Dari definisi tersebut didapati bahwa seseorang yang bertugas sebagai manajer dapat mengarahkan dan mengatur orang lain guna mencapai tujuan organisasi.

Di sisi lain, James A.F Stoner mendefinisikan manajemen sebagai proses pengorganisasian, perencanaan, dan penggunaan SDM supaya mencapai tujuan organisasi yang sudah ditetapkan.

Secara umum, pengertian manajemen merupakan suatu seni dalam ilmu dan pengorganisasian seperti menyusun perencanaan, membangun organisasi dan pengorganisasiannya, pergerakan, serta pengendalian atau pengawasan. Bisa juga diartikan bahwa manajemen merupakan suatu ilmu pengetahuan yang sistematis agar dapat memahami mengapa dan bagaimana manusia saling bekerja sama agar dapat menghasilkan sesuatu yang bermanfaat bagi orang lain maupun golongan tertentu dan masyarakat luas.

Secara etimologis, pengertian manajemen merupakan seni untuk melaksanakan dan mengatur. Manajemen ini juga dilihat sebagai ilmu yang mengajarkan proses mendapatkan tujuan dalam organisasi, sebagai usaha bersama dengan beberapa orang dalam organisasi tersebut. Sehingga, ada orang yang merumuskan dan melaksanakan tindakan manajemen yang disebut dengan manajer.

\section{Fungsi Manajemen}

Pada dasarnya, fungsi manajemen dibagi menjadi tiga, yaitu:

1. Perencanaan (planning)

Pernecanaan adalah memikirkan apa yang akan dikerjakan dengan sumber yang dimiliki. Perencanaan dilakukan untuk menentukan tujuan perusahaan secara keseluruhan dan cara terbaik untuk memenuhi tujuan itu. Manajer mengevaluasi berbagai rencana alternatif sebelum mengambil tindakan dan kemudian melihat apakah rencana yang dipilih cocok dan dapat digunakan untuk memenuhi tujuan perusahaan. Perencanaan merupakan proses terpenting dari semua fungsi manajemen karena tanpa perencanaan, fungsi-fungsi lainnya tak dapat berjalan.

\section{Pengorganisasian (organizing)}

Pengorganisasian dilakukan dengan tujuan membagi suatu kegiatan besar menjadi kegiatan-kegiatan yang lebih kecil. Pengorganisasian mempermudah manajer dalam melakukan pengawasan dan menentukan orang yang dibutuhkan untuk melaksanakan tugas-tugas yang telah dibagi-bagi tersebut. Pengorganisasian dapat dilakukan dengan cara menentukan tugas apa yang harus dikerjakan, siapa yang harus mengerjakannya, bagaimana tugastugas tersebut dikelompokkan, siapa yang bertanggung jawab atas tugas tersebut, dan 


\section{JURNAL ABDIMAS

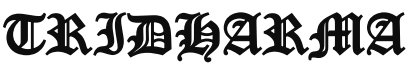

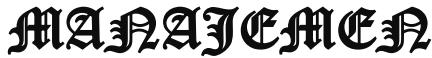

P-ISSN 2615-6849, E-ISSN 2716-070X

Jurnal ABDIMAS Vol. 1,No.2, Mei 2020,Hal(117-124)

@ Prodi Manajemen Fakultas Ekonomi Universitas Pamulang

Email: abdimasjurnal.unpam@gmail.com Telp: (021) 741-2566 pada tingkatan mana keputusan harus diambil.

3. Pengarahan (directing)

Pengarahan adalah suatu tindakan untuk mengusahakan agar semua anggota kelompok berusaha agar dapat mencapai sasaran sesuai dengan perencanaan manajerial dan usaha.

\section{Pengertian Manajemen Pemasaran}

Manajemen adalah ilmu dan seni yang megatur proses pemanfaatan sumber daya manusia dan sumber-sumber daya lainya termasuk manajemen pemasaran secara efektif dan efesien untuk mencapai suatu tujuan tertentu.

Manajemen pemasaran merupakan bagian dari ilmu manajemen yang memfokuskan perhatianya pada pengaturan peranan pemasaran dalam kegiatan organisasi. Hal ini dikarnakan dalam mencapai tujuanya untuk mendapatkan laba operasi, organisasi memerlukan pemasar sebagai ujung tombak bagi tercapainya tujuan organisasi dalam maksimalisasi laba yang diperoleh, sehingga pendapatan yang diperoleh dapat menutupi segala biaya operasi yang timbul dalam aktifitas usaha.

Dalam lingkungan bisnis yang berubah cepat, setiap bisnis harus menang di market yang berubah, pemasaran harus dilihat sebagai "dealing with the market" yang mengharuskan pelaku bisnis sebagai marketer untuk dapat dinamis dan intensif berinteraksi dengan market. Karena pelanggan sangat sensitif terhadap harga, kompetitor baru bermunculan, saluran distribusi/komunikasi baru semakin canggih yang mendukung pasar menjadi pendukung bangkitnya otomasi penjualan dan pemasaran.

Manajemen pemasran merupakan bagian dari manajemen. Oleh karna itu, teori-teori manajemen umum manjadi dasar pembahasaannya mengenai strategi pemasaran yang terencana dalam menentukan tujuan organisasi yang optimal.
Pengaturan itu meliputi masalah marketing mix atau bauran pemasaran yang minimal terdiri dari 4P (product, price, place dan promotion) hal ini perlu dilakukan dalam upaya untuk membantu terwujudnya tujuan perusahaan, karyawan, dan masyarakat.

Bauran pemasaran (marketing mix) merupakan penggabungan berbagai unsur pemasaran menjadi satu kesatuan yang saling terintegrasi dalam aktivitas bisnis. Satu unsur bauran pemasaran akan saling terkait, berhubungan, dan berpengaruh dengan unsur lainnya. Setiap aktivitas bisnis pasti tidak akan terlepas dari bauran pemasaran. Dengan demikian pelaku bisnis harus memahami setiap unsur dari bauran pemasaran agar dapat menentukan kebijakan dan keputusan dengan tepat. Bauran pemasaran terdiri dari empat unsur sebagai berikut:

1. Product (Produk)

Pemasaran dimulai dari produk, produk adalah segala sesuatu yang dapat ditawarkan ke pasar untuk memuaskan kebutuhan atau keinginan konsumen yang mencakup: barang, jasa, pengalaman, kejadian, orang, tempat, properti, informasi dan gagasan.

2. Price (Harga)

Harga adalah keseluruhan nilai yang ditukarkan konsumen untuk mendapatkan keuntungan dari kepemilikan terhadap sebuah produk atau jasa.Bagi konsumen, harga merupakan segala bentuk biaya moneter yang dikorbankan oleh konsumen untuk memperoleh, memiliki, memanfaatkan sejumlah kombinasi dari barang beserta pelayanan dari suatu produk. Bagi produsen, penetapan harga merupakan cara untuk membedakan penawaran dari pesaing.

3. Place (Tempat/saluran)

Istilah place memiliki dua makna, pertama tempat di mana produk dan 


\section{JURNAL ABDIMAS

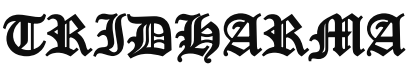

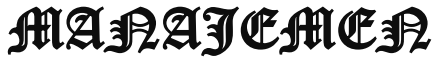

P-ISSN 2615-6849, E-ISSN 2716-070X

Jurnal ABDIMAS Vol. 1,No.2, Mei 2020,Hal(117-124)

@Prodi Manajemen Fakultas Ekonomi Universitas Pamulang

Email: abdimasjurnal.unpam@gmail.com Telp: (021) 741-2566 jasa tersebut dapat diakses oleh konsumen.Semakin banyak tempat yang mudah untuk mendapatkan atau membeli produk/jasa, semakin baik bagi bisnis. Tempat bisnis juga harus disesuaikan denga produk yang dijual dan harga diterapkan. Misalnya, menjual baju yang target pasarnya konsumen menengah ke bawah maka harus memiliki lokasi jualan di tempat-tempat umum, seperti:pasar dan pusar grosir. Namun, jika barang ditujukan untuk kalnagan atas maka harus menjualnya di hotel, mall, ataupun butik. Pemilihan tempat yang benar dan strategis juga akan memengaruhi berhasil atau tidaknya proses pemasaran. Place sebagai saluran pemasaran merupakan suatu fungsi dan sistem jaringan perantara (agen, pedagang, retailler) yang terorganisasi melakukan semua aktivitas pemasaran yang diperlukan untuk menghubungkan produsen dan konsumen.

4. Promotion (Promosi)

Komponen bauran pemasaran yang paling terlihat nyata adalah promosi, yang mengacu kepada teknik-teknik mengkomunikasikan informasi mengenai suatu produk. Promosi sebagai kegiatan perusahaan mengkomunikasikan memperkenalkan produk pasar sasaran.yang juga vital, karena masyarakat akan lebih cepat mengenal dan sadar akan keberadaan produk atau jasa.

\section{METODE PELAKSANAAN}

Persiapan pelaksanaan Kegiatan, antara lain melakukan komunikasi awal tentang rencana kegiatan, melakukan perijinan tempat, survey awal dan melakukan rapat koordinasi tim pelaksana. Melakukan diskusi dengan mitra terkait program yang akan di laksanakan. Diskusi tentang Partisipasi Pengurus Bank Sampah pada khusus nya serta warga dan pengurus pusat bank sampah wilayah kecamatan. Menyusun rencana kegiatan penyuluhan dalam bentuk seminar, dilaksanakan pada tanggal 25 - 27 Oktober 2019.

Kunjungan ke Lokasi Bank Sampah Asri Berseri. Persiapan kebutuhan pendukung bagi kegiatan penyukuhan dan pendampingan diskusi dengan para peserta. Persiapan juga dilakkukan terhadap perangkat yang dibutuhkan. Penyuluhan dalam bentuk seminar yang dibagi dalam 3 sesi materi: Pengenalan Strategi Umum Pemasaran serta Analisis SWOT, Strategi Bauran Pemasaran. dan Penyelesaian Hambatan dan kendala.

\section{HASIL DAN PEMBAHASAN}

Pengabdian Masyarakat (LPPM) Universitas Pamulang yang dilakukan oleh dosen-dosen program studi Akuntansi telah berjalan dengan lancar dan mendapat sambutan hangat dari tempat pelaksanaan kegiatan ini yaitu di Bank Sampah Asri Berseri, Griya Pamulang Asri Benda Baru Pamulang, Tangerang Selatan .

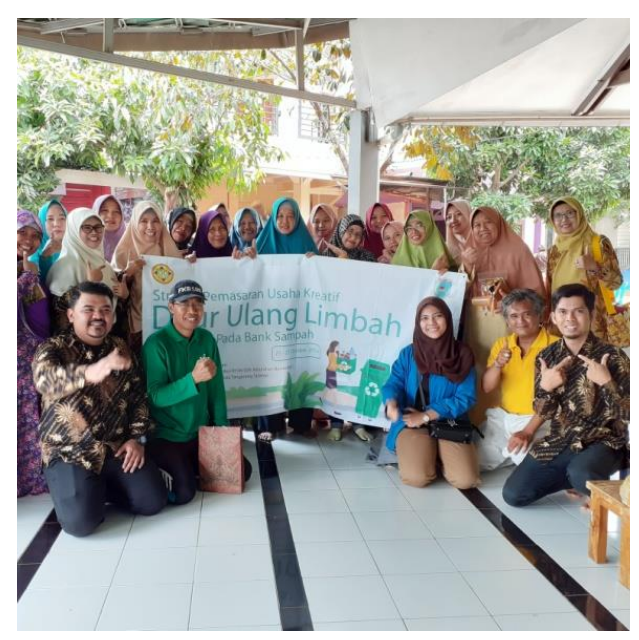

Pengurus dan Anggota Bank Sampah mengerti dan memahami bagaimana pemilihan produk yang berkualitas melalui Bauran pemasaran. Pengurus dan Anggota Bank Sampah Mengerti dan Memahami Bagaimana 


\section{JURNAL ABDIMAS

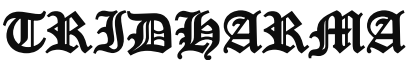

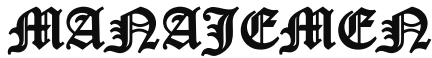

P-ISSN 2615-6849, E-ISSN 2716-070X

Jurnal ABDIMAS Vol. 1,No.2, Mei 2020,Hal(117-124)

@ Prodi Manajemen Fakultas Ekonomi Universitas Pamulang

Email: abdimasjurnal.unpam@gmail.com Telp: (021) 741-2566
Memanajemen usaha bank sampah yang produktif dan efektif. Pengurus dan Anggota Bank Sampah Memahami dan mengerti bagaimana membuat strategi pemasaran agar produk yang dihasilkan mampu terjual banyak. Pengurus dan Anggota Bank Sampah mengerti dan memahami bagaimana memperluas produk yang dihasilkan baik melalui media Ofline atau pun media Online dengan memperlebar jaringan pemasaran. Pengurus dan Anggota Bank Sampah Mengerti dan memahami melalui Analisis SWOT tentang hambatan dan kendala mereka.

\section{KESIMPULAN DAN SARAN}

\section{Kesimpulan}

Dari hasil kegiatan Pengabdian Kepada Masyarakat ini dapat disimpulkan bahwa: Untuk bisa menghasilkan nilai ekonomis suatu barang, dapat berupa apapun termasuk sampah daur ulang khususnya anorganik Dengan mulai maraknya pengetahuan masyarakat terkait pengolahan sampah menjadikan masyarakat berusaha mengelolah sampah menjadi suatu produk yang bernilai tinggi dapat dipasarkan. Sebagian masyarakat dengan kecanggihan era industry saat ini belum memahami strategi yang efektif dan efisien dalam memasarkan produk baik secara offline ataupun secara online. Sebagian Masyarakat masih mengembangkan usaha kreatif mereka secara individu dan tradisional sehingga sulit untuk berkembang menjadi industry yang terintegrasi dan aplikatif.

\section{Saran}

Mengingat besarnya manfaat dari kegiatan Pengabdian Kepada Masyarakat ini, maka saran yang diberikan adalah untuk Memperlebar pengetahuan dan pemahaman strategi pemasaran produk - produk khusus nya olahan sampah daur ulang ke wilayah yang lebih luas. Membuat tindak lanjut dari hasil penyuluhan ini untuk melihat progress dan hasil yang sudah dilakukan.
Mengadakan lanjutan penyuluhan kembali dari program penyuluhan sebelumnya.

\section{DAFTAR PUSTAKA}

Aminudin. 2013. Manfaat Daur Ulang Sampah.

http://www.aminudin.com/2013/06/manfaa t-daur-ulang-sampah.html . Diakses pada tanggal 29 september 2019.

Anggani, Sri. 2014. Kreasi Daur Ulang. Jakarta: Gramedia Pustaka Utama.

Anonym. 2012. Pengolahan Sampah. http://www.isomwebs.net . Diakses pada tanggal 29 september 2019.

F., Firdha. 2010. Daur Ulang Sampah. http://firdhaf08.student.ipb.ac.id/2010/06/1 9/daur-ulang-sampah.html . Diakses pada tanggal 29 september 2019

Faizah. 2008.pengelolaan sampah berbasis masyarakat.semarang:unniversitas

Diponegoro.

Ishariatiz,2012,"Bank

Sampah"; Yogyakarta

Kban, Jabat. 2012. Bisnis Kreatif Kerajinan Daur Ulang Limbah. Yogyakarta: Majalah Bisnis UKM.

Qardhul Hasan: Media Pengabdian kepada Masyarakat p-ISSN 2442-3726 e-ISSN 2550-1143 diakses pada tanggal 29 september 2019

https://www.tokomesin.com

https:/m3penyuluhanfapetub2017bloh.wor dpress.com 


\section{JURNAL ABDIMAS

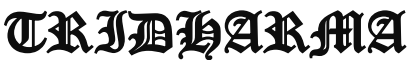

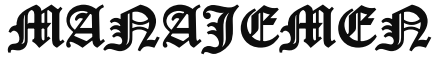

P-ISSN 2615-6849, E-ISSN 2716-070X

Jurnal ABDIMAS Vol. 1,No.2, Mei 2020,Hal(117-124)

@Prodi Manajemen Fakultas Ekonomi Universitas Pamulang

Email: abdimasjurnal.unpam@gmail.com Telp: (021) 741-2566

\section{DOKUMENTASIFOTO KEGIATAN}
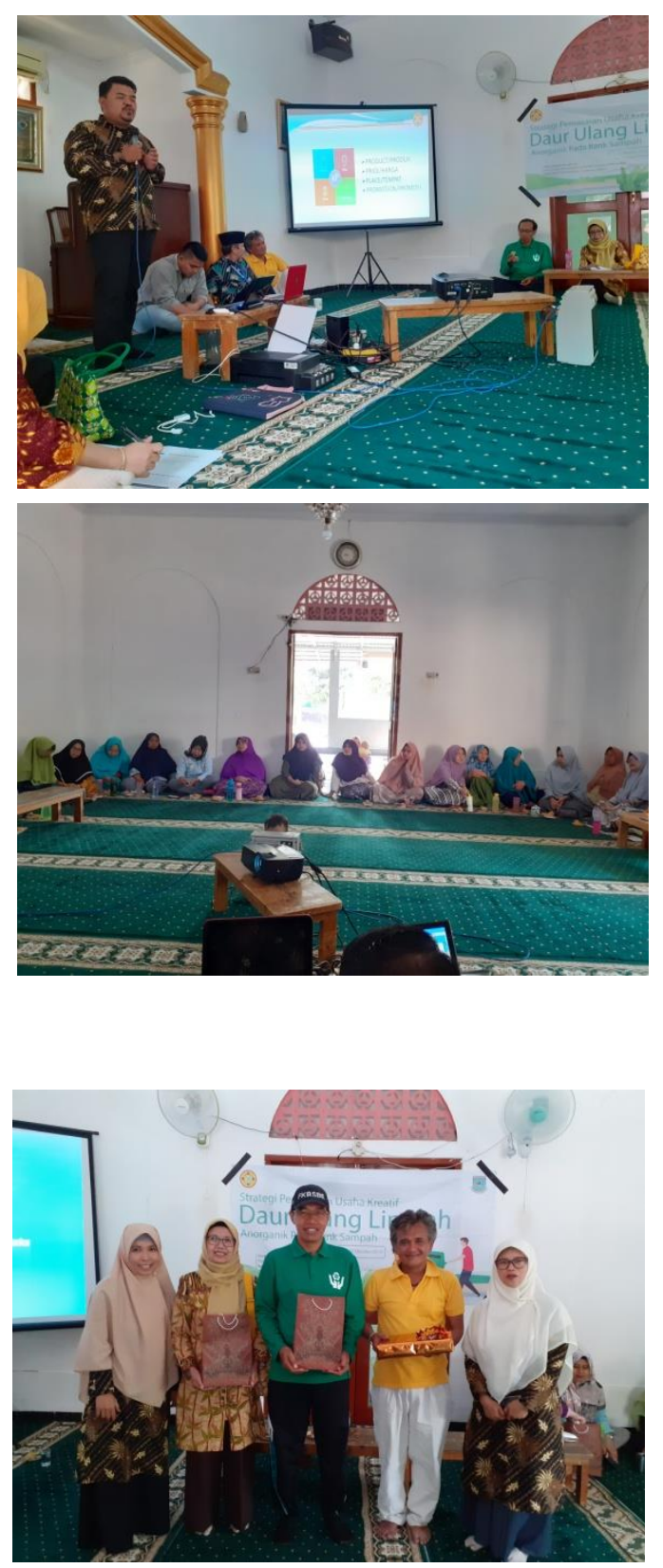
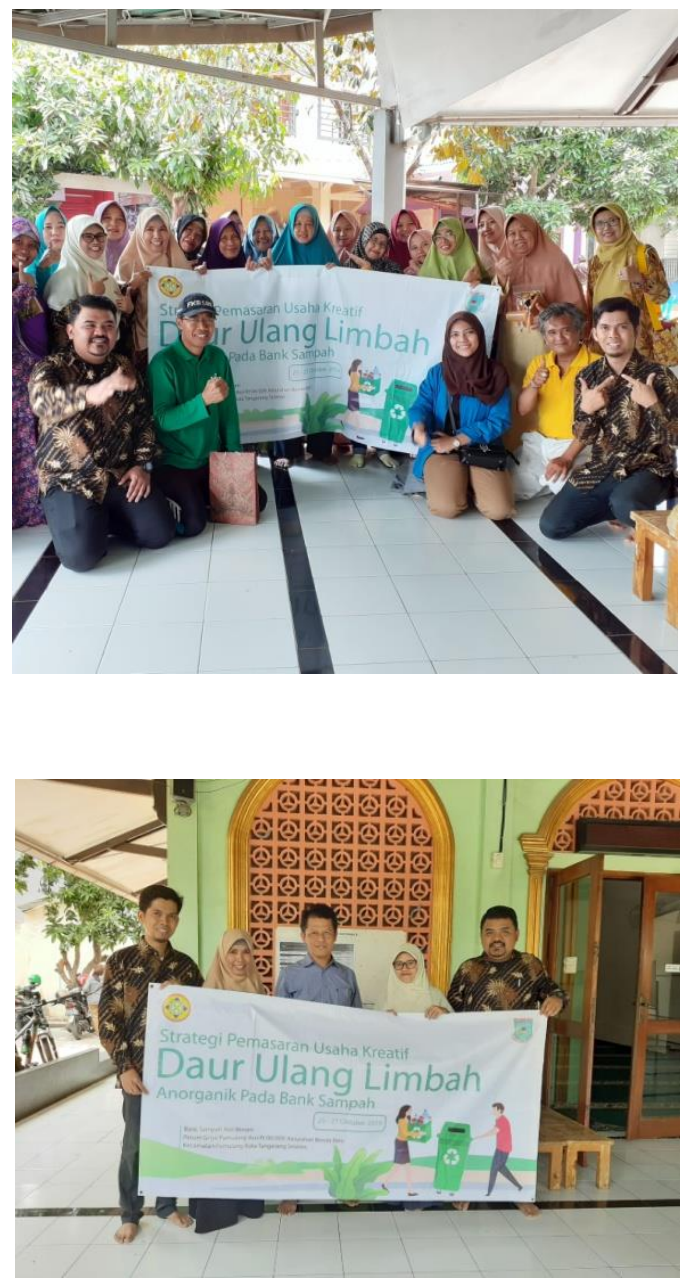